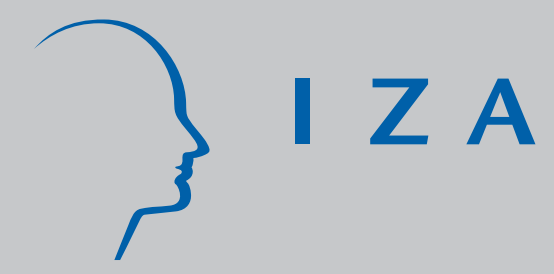

IZADP No. 3352

Better Protected, Better Paid: Evidence on How Employment Protection Affects Wages

Karen van der Wiel

February 2008 


\title{
Better Protected, Better Paid: Evidence on How Employment Protection Affects Wages
}

\author{
Karen van der Wiel \\ CentER, Tilburg University, \\ Netspar and IZA
}

\section{Discussion Paper No. 3352 \\ February 2008}

\author{
IZA \\ P.O. Box 7240 \\ 53072 Bonn \\ Germany \\ Phone: +49-228-3894-0 \\ Fax: +49-228-3894-180 \\ E-mail: iza@iza.org
}

Any opinions expressed here are those of the author(s) and not those of IZA. Research published in this series may include views on policy, but the institute itself takes no institutional policy positions.

The Institute for the Study of Labor (IZA) in Bonn is a local and virtual international research center and a place of communication between science, politics and business. IZA is an independent nonprofit organization supported by Deutsche Post World Net. The center is associated with the University of Bonn and offers a stimulating research environment through its international network, workshops and conferences, data service, project support, research visits and doctoral program. IZA engages in (i) original and internationally competitive research in all fields of labor economics, (ii) development of policy concepts, and (iii) dissemination of research results and concepts to the interested public.

IZA Discussion Papers often represent preliminary work and are circulated to encourage discussion. Citation of such a paper should account for its provisional character. A revised version may be available directly from the author. 
IZA Discussion Paper No. 3352

February 2008

\section{ABSTRACT \\ Better Protected, Better Paid: Evidence on How Employment Protection Affects Wages}

This paper empirically establishes the effect of the employer's term of notice on the wage level of employees. The term of notice is defined as the period an employer has to notify workers in advance of their up-coming dismissal. The wages paid during this period are an important element of firing costs and hence employment protection. To find a causal effect, I exploit the exogenous change in the term of notice that resulted from the introduction of a new Dutch law in 1999. Strong evidence is found that a longer 'dormant' term of notice leads to higher wages. In my sample, an additional month of notice increases wages by three percent, ceteris paribus.

JEL Classification: $\quad$ C23, J31, J38, J63

Keywords: employment protection, wages, fixed effects

Corresponding author:

Karen van der Wiel

Tilburg University

Department of Econometrics and OR

P.O. Box 90153

5000 LE Tilburg

The Netherlands

E-mail: K.M.vdrWiel@uvt.nl

\footnotetext{
* Thanks to Arthur van Soest, Jan van Ours, Frederic Vermeulen, Gerard Pfann, Anja Deelen, Bas ter Weel, Davida van Praag and several seminar participants for useful comments and suggestions. The Dutch government institution that pays out social security benefits, the Sociale Verzekeringsbank, generously funded this research.
} 


\section{Introduction}

Employment protection legislation (EPL) has been on the (European) political agenda for several decades and continues to be widely debated. On the one hand employers complain that they are incapable of adapting to economic circumstances because of high firing costs and on the other hand vulnerable groups of employees complain that the firing risk they face is too large. Policy-makers in the meantime have to decide upon an optimal level of protection. In order to make such decisions politicians need to know how different types of employment protection affect labor market outcomes. In order to provide such answers, a large economic literature on employment protection has developed.

The rationale for installing employment protection legislation is clearly not to manipulate wages. In practice EPL might however have a considerable impact on them. In fact, this impact is a central issue in the academic EPL literature as it is closely related to the effect of employment protection on employment levels ${ }^{1}$. How these two labor market outcomes are theoretically related depends on the type of employment protection under investigation, on the relevant labor market institutions and on which further assumptions the respective researcher makes. An efficiency wage theorist such as Lazear (1990) for example considers a competitive economy with individual wagesetting and firing costs that will be transferred to dismissed workers. In his model, wages will adjust downwards to take the firing costs into account and employment will not be affected. Alternatively, Bertola (1990) assumes central wage bargaining by a union who cares for incumbent workers only and a general turnover cost associated to dismissals. According to insider/outsider theory, employment protection will then bring unions to bargain for higher than competitive wages. As a result, firms will fire (and hire) fewer workers.

Empirically, only anecdotal evidence of the true relationship between employment protection and wages exists. This is partly because most empirical research has analyzed macro-data and composite employment protection indices, which introduces comparability issues and confounding factors into the estimations. This paper seeks to use a micro panel dataset to empirically establish the causal effect of a specific type of employment protection, namely the employer's term of notice (ToN), on the wage level of employees. The term of notice is defined here as the amount of time an employer has to notify an employee in advance of her upcoming dismissal. Specific groups, notably older workers, are often protected by a longer term of notice. The term of notice is usually ignored in the empirical employment protection

\footnotetext{
${ }^{1}$ In this paper I don't directly discuss the empirical effect of employment protection on employment, as I am currently working on a paper that will deal with the causal relationship between employment protection and lay-offs. In this forthcoming paper I estimate a job duration model exploiting the same exogenous change in employment protection as in the current paper.
} 
literature. This is unjust as a long term of notice corresponds to a large number of obligatory wage payments and hence is a substantial firing cost to the employer.

The Dutch labor market has two relevant features that makes it suitable as a research ground for this paper. First, for each worker, it is possible to calculate the 'dormant' term of notice that would apply in case the employer would want to fire her. This is because the law sets out a formula to calculate the term of notice, which generates variation in the degree of employment protection for workers of different age and tenure. Second, in 1999 the legal formula to calculate the term of notice was changed in The Netherlands. This paper will exploit this exogenous policy change to answer the causality question and to separate the age, tenure and term of notice effects on wages. Low-tenured workers benefited from the introduction of the law on flexibility and security as their employer's term of notice increased but higher tenured workers experienced a shorter term of notice after the 1st of January 1999.

The remainder of this paper presents evidence of a strong positive causal effect of the term of notice on wages. It is nevertheless demonstrated that regressions that ignore the micro-econometric difficulties involved can overestimate this effect. Section 2 discusses the most important findings in the employment protection literature on wages. Section 3 then lays out the term of notice regulations in The Netherlands and the changes introduced in the law of flexibility and security ('Flexwet'). The econometric issues that complicate the identification of a causal effect and also the employed fixed effects methodology are explained in section 4 . The utilized data are discussed in Section 5 and results will be presented in Section 6. Section 7 concludes.

\section{Literature}

\subsection{Theoretical literature}

An extensive theoretical literature looks into the effects of employment protection (i.e. firing costs) on the labor market. Concerning wages, the predictions of what EPL actually does vary greatly. Many of these differences result from considering different types of employment protection and different types of labor market institutions. I will explain most views in this section, although I do not pretend to be exhaustive.

Walter Oi published the seminal paper in the employment protection literature in 1962 as he was the first to model labor as a quasi-fixed production factor and labor costs as having a fixed component related to hiring and firing costs. Many authors followed in his footsteps by building partial equilibrium models of labor demand, meanwhile introducing different structures of the labor adjustment costs (e.g. Bentolila and Bertola, 1990). Wages are however exogenous in the greatest part of this literature. As the effect of 
employment protection on employment is important when considering the effect of employment protection on wages, I will however explain Bentolila and Bertola's argument below.

Whether a profit-maximizing firm decides to fire a worker primarily depends on the productivity and wage of the worker ${ }^{2}$. When the difference between these entities is negative, an employer loses money and she will consider to fire the worker. It is costly however to adjust the number of employees downward because of firing costs.

Firing costs comprise of two elements: taxes to be paid outside the job-worker pair and transfers from the firm to the worker (Garibaldi and Violante, 2005, p.799). Legal costs associated with layoffs fall under the first type, whereas the term of notice and the severance pay fall under the second type of employment protection. The length of the term of notice, or the number of additional wage payments, partly determines the size of the transfer firing costs. When the gap between an individual's wage and productivity is large, these costs are substantial. To illustrate the costs associated with the term of notice, I take a fifty year-old female worker from my sample employed at a firm for twenty years, working for 38 hours a week. Before 1999, her employer was obliged to notify her 18 weeks before an upcoming dismissal. If I assume that the fired worker was (demotivated and therefore) completely unproductive over that period, her employer would have lost on average 26,361 (2005 real) Dutch guilders, which equals 11,962 euros.

Getting back to Bentolila and Bertola's argument: attracting a new employee in the future will also be costly to the employer because of hiring and training costs. Hence it could be profitable to defer the irreversible decision to fire a worker in order to circumvent adjustment costs. The firm will indeed do so when either the probability of a productivity change for the better or the costs of hiring and firing are sufficiently large. According to the adjustment costs literature, higher firing costs, e.g. a longer term of notice, thus lower the propensity to fire a worker when wages are fixed. Note that the overall impact of employment protection on employment levels is unclear however, as the propensity to hire also goes down.

As mentioned already, most of the employment demand literature takes wages to be exogenous. One exception is Bertola (1990) who draws from the insider-outsider literature (see Lindbeck and Snower, 2001, for an overview of this literature). In short, insider/outsider theory divides the labor market into insiders - incumbent workers who benefit from employment protection - and outsiders - those who do not benefit such as the unemployed and temporary workers. Because it is difficult to get rid of them, insiders have

\footnotetext{
${ }^{2}$ This paper considers individual lay-offs. Individuals can be fired because of financialeconomic or match-specific problems, say when there is a conflict between the employer and the employee. Although the latter probably plays a considerable role in observed lay-offs, this paper focuses on the financial firing rationale.
} 
some bargaining power in the wage process and hence demand higher than competitive wages (for a formal model, see Lindbeck and Snower, 1986).

In his paper, Bertola looks at how employment protection affects wages under different wage setting institutions. First, he investigates labor demand and endogenous wages when wage negotiations take place at the individual level. He finds that under certain assumptions total received wages might not be affected, although outsiders might offer to work for a very low wage in order to become an insider and although insiders might afterwards rise wage demands above the competitive level. This would be because, in a competitive economy, these two effects cancel out. Second, Bertola assesses wages when there is a wage setting union that cares for everyone in the labor market. Also in this case, he concludes that lifetime wages would remain unaffected. Only in the instance of unions who solely represent working members does employment protection increase total labor income for insiders indefinitely.

The idea that a country's wage-setting institutions influence the causal effect of employment protection on wages is also exploited in a search and matching model framework by Garibaldi and Violante (2005). The authors built a model with endogenous wage setting behavior by a monopolistic union. Garibaldi and Violante (2005) stress that in such a setting the introduction of an exogenous firing cost has two opposing effects on the workers' desired wage level: workers would like to have a higher wage (the income effect) but do not enjoy the accompanying higher probability to get fired (the job security effect). Whenever the elasticity of the firm's firing probability to wages is low enough, workers will demand higher wages when they are better protected.

Efficiency wage theorists shed a different light on firing costs and wages. Lazear (1990) wrote an influential paper on employment protection, arguing that firing costs do not necessarily affect hirings and firings. He reasons that in a flexible labor market, in the absence of contract and market restrictions, transfer employment protection such as the term of notice could be undone by efficient wage setting behavior between workers and firms. He predicts that in a competitive economy with decentralized wage setting, firing costs drive wages down, up to the point where the severance pay and the wages paid during the term of notice can be seen as a delayed payment.

Lazear's negative effect of employment protection on wages is replicated by Pissarides (2001), but the latter takes the workers point of view. In his search and matching model the term of notice is endogenous and generates lower wages because risk averse workers accept a lower income during the productive period of a job, in order to receive a higher income during unproductive times. Bertola and Rogerson (1997) adapt a similar reasoning. If workers are risk-averse and value job security, they will accept lower wages in exchange for more employment protection.

Because the literature above thinks about workers as having fixed or at 
least exogenous productivity, it leaves out another important route through which employment protection positively affects wages. More employment protection namely enhances the incentives for a firm to invest in a worker and for a worker to invest in firm-specific human capital. Nickell and Layard (1999) briefly describe this effect. These human capital investments could pay off in terms of higher productivity and higher wages. Arulampalam et al. (2004) present some indirect empirical evidence that employment protection does increase training of employees. They find that those on fixed term contracts take up less training than those on permanent contracts.

To summarize the theoretical insights so far: On the one hand the term of notice could increase wages. Two main arguments are discussed. First, insider-outsider theory predicts that employment protection improves insiders' bargaining position when there is some degree of centralized wage bargaining. Second, employment protection could stimulate human capital investments and hence increase individuals' productivity. On the other hand, the term of notice could decrease wages. Three arguments are provided. First, the term of notice, being a transfer component of employment protection, could be compensated by lower wages in a competitive economy with individual wage-setting. Second, if the term of notice is endogenous, workers are willing to accept a lower wage in order to have the job security associated with a term of notice. Third, employment protection might not induce workers to increase their wage demands out of fear of the associated increase in firing probabilities. The latter two arguments hold even in a more centralized wage-setting environment.

The most appropriate theories for my empirical study are the ones involving some market imperfections and moderate centralized wage-setting. Lazear's argument is hence not likely to hold in the Dutch economy, in which employers organizations and a small number of labor unions negotiate over wages by industry. For more information on wage setting in The Netherlands see Wallerstein et al. (1997). Even excluding the efficiency wage argument there are however still opposing predictions on the causal effect of employment protection on wages. The data will have to judge which of these hold.

\section{$2.2 \quad$ Empirical literature}

Up to date, the empirical literature has experienced difficulties in establishing a clear relationship between firing costs and wages. Some of the papers discussed in the previous subsection do attempt to present empirical evidence of their models. However, the authors only provide anecdotal evidence of their theory at best, mainly because most of them use macro-data and aggregate indices of employment protection that are hard to compare. The estimates are furthermore troubled by confounding factors. Contrary to what his theoretical model predicts, Bertola (1990) for example presents 
some evidence that the productivity wage gap is actually lower in countries with stricter employment protection.

The empirical wage setting literature in its turn often ignores employment protection as it is so hard to quantify. See for example the crosscountry study of industry wage differentials by Holmlund and Zetterberg (1991) and the establishment-level study by Blanchflower et al. (1990). Both papers do suggest substantial insider wage gains.

An interesting firm-level study by Autor et al. (2007) does include employment protection, i.e. tax employment protection, explicitly. The paper exploits U.S. state variation in the adoption of wrongful-discharge protections in order to study firm-level productivity differences. The authors find that the introduction of these laws coincided with a rise in capital investment, non-production worker employment and hence measured a labor productivity increase. Whether these effects can be causally linked to the wrongful-discharge protection remains to be seen. Even so, this study fails to measure the impact of employment protection on individual workers.

The use of micro-data in the empirical employment protection literature, which seems to be a necessary prerequisite for identifying causality, is unfortunately limited. The fact that wages are usually very heterogeneous across workers of different ages, tenure, education and hierarchy provides another rationale for individual-level empirical analysis. The only microstudy on employment protection and wages that I am aware of is written by Leonardi and Pica (2007). They apply a regression discontinuity design to study entry wages and the tenure wage profile by exploiting an Italian policy change. The authors find no causal effect of severance payments on entry wages. This policy change in employment protection legislation was targeted at small firms only, which raises questions about the generality of the conclusions.

My paper is, as far as I know, the first to identify a strong positive causal relationship between transfer employment protection and wages using a representative micro panel dataset. One of the many advantages of this empirical strategy is that it allows me to control for the effect of employment protection on dismissals. This is because I follow the same individuals over different years and if applicable over different jobs, so given that a fired worker finds a job again after some time I will observe that person's wage again.

\section{Term of notice}

There are two paths to dismissal in The Netherlands, and the legal term of notice only applies to the labor office path. This is a relatively slow route that doesn't require severance payments. The labor office has the discretion to refuse an application, but only does so in a small percent of the cases 
(i.e. five percent in 2002). Mainly individual lay-offs in small- and medium sized firms and collective lay-offs are dealt with by the labor office, but the path is open to all employers. The other route, through court, is faster and involves substantial severance payments ${ }^{3}$. The cantonal court judge in principle always allows a lay-off but adapts the required severance payment to the specific firing rationale (i.e. a worker receives more if the employer could have done more to prevent the lay-off $)^{4}$.

An employer is free to choose a dismissal path and the labor office path is thus a credible threat to all workers. Furthermore, nothing changed in the court procedure over the analyzed period. This means that the employer's term of notice and the policy changes to it are relevant to all employees on a permanent contract.

The policy change that will be exploited in the fixed effects method below is the introduction of the law on flexibility and security (the 'Flexwet') in The Netherlands on January 1st, 1999. This law intended to diminish differences in the labor market between temporary and permanent workers. On the one hand, employees with temporary contracts received better legal protection than before. On the other hand, employees with permanent contracts lost some rights. The main change for tenured employees was the adaptation and simplification of the legal formula for the term of notice. See Heerma van Voss (1998) or Smitskam and Kronenburg-Willems (2000) for a detailed description of the new law.

The calculation of the term of notice before the 1st of January 1999 (old-ToN) was as follows. For every year of tenure an employer had to add a week to the notice period, with a maximum of thirteen weeks. On top of this, workers received an extra week of notice for each year they had worked while being forty-five or older, also with a maximum of thirteen weeks. So, the employers of two workers with identical tenures (say fifteen years) but different ages (say forty and sixty) faced different terms of notice (in this case thirteen weeks and twenty-six weeks).

The legal term of notice after the 1st of January 1999 (new-ToN) consists of two elements: a new formula for newly-hired employees and a transitory arrangement for workers already employed at the introduction of the 'Flexwet'. The new formula that applies to employees hired after the 1st of January 1999 does not depend on age and accommodates fewer term of notice lengths. For workers employed in between zero and four years employers

\footnotetext{
${ }^{3}$ Figure A-1 in the appendix shows the ratio of lay-offs through the labor office over the total number of lay-offs. A constant percentage of about fifty percent of lay-offs are handled by the labor office. A small increase in the ratio can be seen in 1999, the year the legal term of notice was changed. It can be argued that the labor office procedure became more profitable that year because the term of notice went down for the majority of workers.

${ }^{4}$ In a limited amount of cases a cantonal court judge refuses to end the labor contract, for example when a sick worker is dismissed because of her illness.
} 
face a term of notice of one month. When a worker is employed between five and nine years, employers have to notify her two months in advance. If a worker's tenure is between ten and fourteen years, her employer will have to notify her three months in advance. Any tenure longer than fourteen years results in an employer term of notice of four months.

The 'Flexwet' also includes a transitory arrangement for those workers that were already employed by the 1st of January 1999. For these employees, the employer picks the longest term of notice out of the old-ToN calculated for the tenure and age situation on the 1st of January 1999 and the new-ToN for the tenure and age at the time of firing.

In addition, for both workers in the new and the transitory scheme, the new law allows employers to deduct one month of the term of notice if they have waited to end the labor agreement until after they have received permission from the labor office. The minimum term of notice however is one month. This subtraction is granted in almost all cases (i.e. ninety-six percent in 2002). In my 'dormant' term of notice calculations I assume that this permission is given in all cases.

The relationship between the old and new term of notice thus depends on age and tenure of the worker and calendar time. Figure 1 shows the oldand new-ToN for the respondents in my dataset over tenure and selected ages. Wherever there are multiple terms of notice visible for an age-tenure combination this is because of time differences, i.e. because the date for which the term of notice is calculated is closer to or further from the 1st of January 1999. So, the employers of two workers with identical tenures (say fifteen years) and age (say sixty years) but fired at different times (say at the 1st of February 1999 and at the 1st of February 2002) will face different terms of notice (in this case five months and four-and-a-half months).

The graphs for the thirty-year and forty-year old worker are identical, the latter only has a larger domain as no thirty-year old is observed with a tenure over seventeen years. When comparing the old- and new-ToN for young workers with a tenure below five years, the new term of notice is longer than before. For young workers with a tenure above fourteen years the old and new term of notice are the same. Young workers with a tenure in between - from five to fourteen years - experience a new term of notice that is shorter than the old-ToN.

The graphs for the fifty-year and sixty-year old worker share important characteristics. For older workers (i.e. from forty-six years onwards) with a tenure below three years the new term of notice is longer than before. This threshold is lower for older workers as the old age reward leads to a higher old term of notice slope ${ }^{5}$. The term of notice of older workers with a tenure of three years and over is shortened in the new scheme. The extent of the difference depends on age and tenure of the worker and time.

\footnotetext{
${ }^{5}$ For 46 year-old workers the threshold is actually four years of tenure.
} 
Figure 1: Employer's Term of Notice in old (pre 1999) and new (1999 and after) scheme by tenure for selected ages of workers $(\mathrm{N}=2,845)$

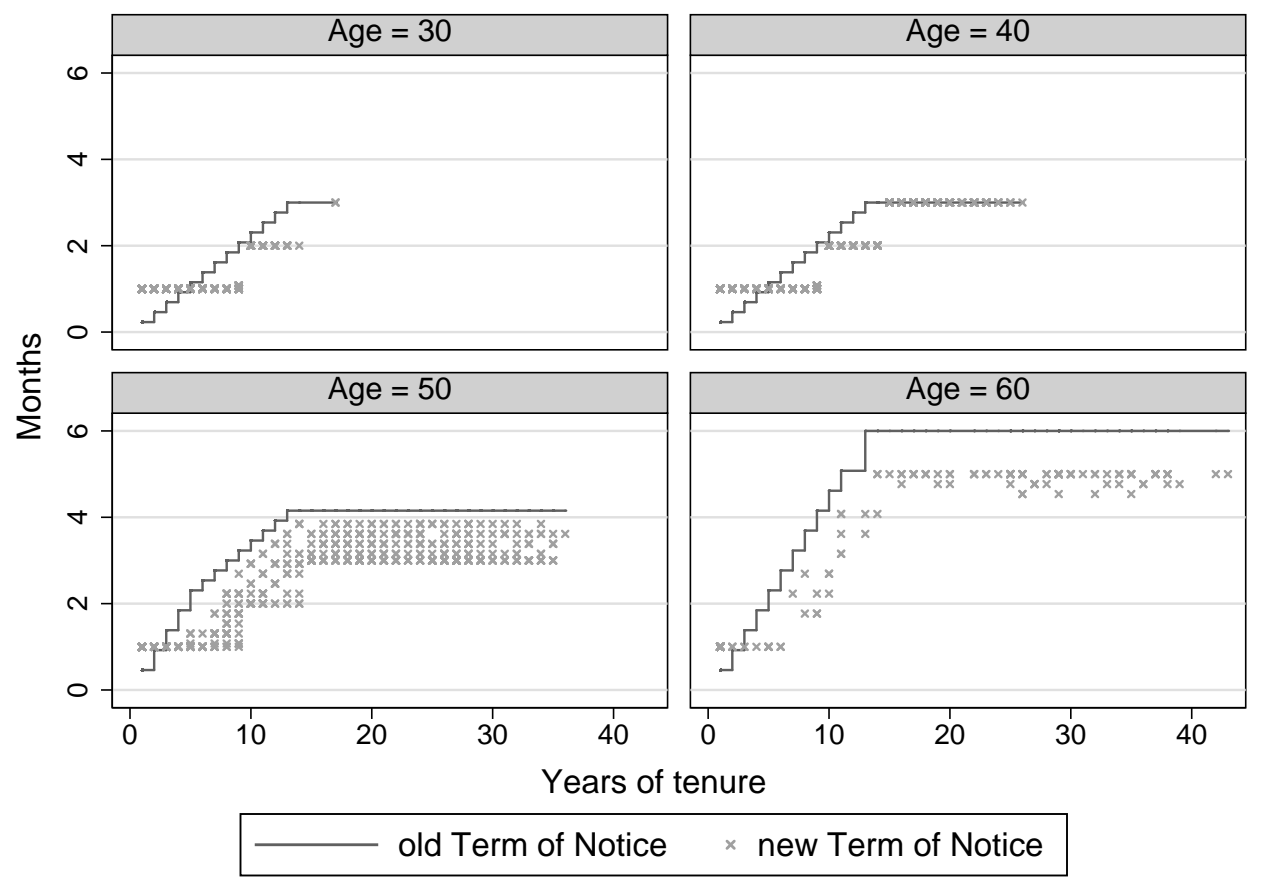


Although the length of the term of notice that applies in the labor office path is set out by law, the 'Flexwet' made it possible to agree upon a different term in a collective wage agreement. For the analysis in this paper it is important to know to what extent this occurred ${ }^{6}$. Combining information from the Ministry of Social Affairs and Employment and my own calculations $^{7}$ I find that after the 1st of January 1999 the legal term of notice applied to eighty percent of workers. If the deviation from what is written down in the law is orthogonal to the type of worker in my sample, I can treat the bias resulting from measurement error as an attenuation bias. This bias will drive the coefficient of the term of notice down. Any significant results that I find will hence be underestimating the true causal effect of the term of notice. In the Smits and Samadhan report the distribution of deviations over sectors seems rather equal. Therefore, and because it is hard to know which agreement specifically applies to which worker, I abstract from the deviation in the collective wage agreements and assume that the legal term of notice applies to everyone.

For longer tenured employees the introduction of the law on flexibility and security thus resulted in a lower term of notice, but for shorter tenured workers the term of notice increased. This variation in the direction of the policy change will prove useful in identifying the causal effect of the term of notice on wages in Section 6.

\section{Empirical strategy}

In this paper I would like to find out what is the relationship between the 'dormant' term of notice and wage rates. Merely reporting the association between the two variables is not enough, I am interested in the causal effect of the term of notice, which is not trivial to identify. Several econometric difficulties trouble the identification of a causal effect of the term of notice.

All issues arise from the fact that for each employee the term of notice, at least in The Netherlands, is determined by a fixed formula of tenure and

\footnotetext{
${ }^{6}$ Smits (2000) and Smits and Samadhan (2002) report that the one month deduction, with a minimum term of notice of one month, prevailed in practically all agreements settled after the 1st of January 1999.

${ }^{7}$ About twenty percent of the workers do not fall under any sort of collective agreement and hence the legal term of notice will always apply to them. The other eighty percent of workers do fall under a collective agreement. I checked half of the collective wage agreements that were declared to hold for all workers in the relevant sector between 1999 and 2002 and found that roughly seventy percent of these featured the term of notice set out in the 'Flexwet'. In sixteen percent of the cases a term of notice calculation that is related to age and tenure still existed. In fourteen percent of the analyzed collective wage agreements I found a constant term of notice. If I assume that the distribution of workers is equal across the different agreements I conclude that eighty percent of workers on a permanent contract face the legal term of notice after January 1st 1999.
} 
age.

$$
\operatorname{ToN}_{i t}=f\left(\text { Tenure }_{i t}, \text { Age }_{i t}\right)
$$

Hence, the term of notice is a deterministic, non-linear function of these two variables. In fact, apart from calendar time (which determines under which legal framework a worker is fired) nothing else influences the employer's term of notice. The analyzed wage model can be seen in equation 1 , where $X$ refers to personal characteristics, $Z$ to employer and job characteristics, $\varepsilon_{i t}$ to an i.i.d error term and $v_{i}$ to an individual-specific time-invariant error term.

$$
\text { Wages }_{i t}=h\left(\operatorname{ToN}_{i t}\left(\text { Tenure }_{i t}\left(v_{i}\right), \text { Age }_{i t}\right), X_{i t}, Z_{i t}\right)+v_{i}+\varepsilon_{i t}
$$

The first econometric problem that I encounter is that of the endogeneity of tenure. Tenure is an endogenous variable, because unobservable characteristics such as work attitude and ability influence tenure as well as wages. As a result of the fixed formula that calculates the term of notice from tenure this endogeneity stains the term of notice variable as well. Running a regression of wages on the term of notice will thus result in a biased and inconsistent coefficient for the term of notice as changes in the term of notice will be associated with changes in the time-invariant individual specific error term. The endogeneity of tenure and the term of notice can and will be addressed by applying a fixed effects type estimator. Section 4 further explains the applied methodology.

Unfortunately, in the wage model the fixed effects approach doesn't result in unbiased estimates of the term of notice coefficient. An extreme multi-collinearity problem arises when the important covariates tenure and age are included in $X_{i t}$. This econometric problem is another consequence of the fixed formula for the term of notice. The marginal effect of the term of notice on wages can thus never be determined ceteris paribus. This is because when the term of notice changes from one year to the next this coincides with a change in tenure and age. In a traditional regression model, it is therefore hard to know what is captured in the term of notice coefficient. This multi-collinearity can be demonstrated in two ways. First, the pairwise correlation between tenure and the term of notice in my sample before 1999 $(\mathrm{N}=10,549)$ is 0.88 . Second, the variance inflation factor $(\mathrm{VIF})^{8}$ of the term of notice in the wage model before 1999 is equal to 10.98 .

To nevertheless answer the research question, one can exploit an exogenous change in the term of notice that does not coincide with a change in tenure and age. To identify a causal relationship between the term of notice and wages this paper therefore exploits the exogenous policy change

\footnotetext{
${ }^{8}$ Variance inflation factors $\left(\frac{1}{1-R_{j}^{2}}\right)$ can be used to track down multi-collinearity problems. $R_{j}^{2}$ refers to the multiple correlation coefficient between variable $\mathrm{j}$ and all other independent variables. A VIF over 10 indicates severe collinearity of higher orders between the specified variable and the remaining regressors.
} 
described in Section 3, the introduction of the law on flexibility and security in The Netherlands. It is not necessary to apply any specific type of policy evaluation method however. The fixed effects OLS regressions will 'automatically' take into account the exogenous variation in the term of notice as the before and after term of notice calculations are included in the individual means.

The 1999 policy change has certain traits that are econometrically useful. First, the introduction of the new law has differential effects across individuals; this makes it possible to separate time and treatment effects. Section 3 explains that the new law increased the term of notice for low-tenured individuals and decreased the term of notice for high-tenured individuals.

Second, selection into a particular treatment group (i.e. into what effect the policy change has on one's term of notice) can fully be controlled for, as the impact of the policy change depends only on age and tenure. By controlling for these two entities and by removing the individual unobserved heterogeneity term the potential selection issues can be overcome. Note that I assume that selection into low or high tenure does not depend on the potential, individual impact of the policy change. This makes sense as I believe it impossible that people quit and start a new job, just for the sake of benefiting from a policy change in the term of notice. It should be remembered that high tenured individuals experience a higher level of employment protection in general, although the policy change does lower it somewhat. It would therefore be irrational to wilfully exchange this better protection for an improving, but still worse protection.

Third, as selection into the treatment depends on observable characteristics only, I can even control for differential wage trends for the groups who are affected by the policy change in a different way. Economic circumstances and other policy changes could for example have a differential impact on the wage trends for low- and high tenured individuals over the analyzed period. By adding interaction terms between the period after the policy change and a dummy for tenure over two years and a dummy for age over 45 I control for the different time trends (Note that these thresholds are important for the effect of the policy change). In table 1 in Section 6 I show that the wage trends for these groups are indeed very different.

The causal effect I'm interested in can thus be obtained as the marginal effect of the term of notice variable in a regression of wages on the term of notice, tenure, age groups, time dummies, a dummy for tenure above two years, a dummy for age over 45 , the interactions described above and several covariates. In order to do so, equation 2 is estimated as a fixed effects linear regression model using the log of the real gross hourly wage rate as the dependent variable. In this equation $\mathbf{x}_{\mathbf{i t}}$ refers to all other controls and covariates.

$$
\text { Wages }_{i t}=\alpha+\beta_{\text {ToN }} * T o N_{i t}+\beta_{2} * \text { tenure }_{i t}+\mathbf{x}_{\mathbf{i t}}^{\prime} \gamma+v_{i}+\varepsilon_{i t}
$$


Figure 2: Kernel density estimation of the hourly wage rate $(\mathrm{N}=21,080)$

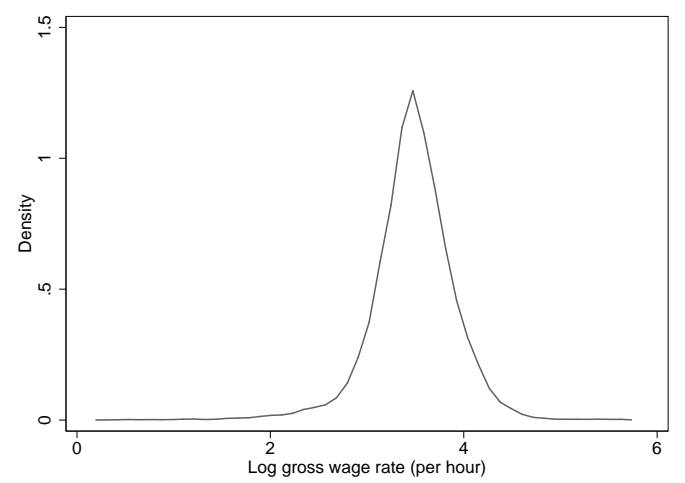

\section{Data}

Six waves of the Dutch Socio-Economic Panel (SEP), a household survey, are used for the empirical analysis of the research question (1996-2001). This longitudinal dataset has been collected annually by Statistics Netherlands from 1984 to 2002. The SEP has been collected every April. Although the same individuals are observed multiple times in my sample, I do not have a balanced panel. I observe 57 percent of the individuals both before and after the policy change, 19 percent only before and 23 percent only after.

I use all available waves before and after the 1999 policy change that contained information on the type of contract a worker was on and that contained comparable wage information. Only employees with a permanent contract are included in the sample. This is because only for tenured workers employers face a legal term of notice.

The dependent variable in the wage regressions is the logarithm of the real gross hourly wage rate. Net wages are not directly observed. Over the analyzed period there were no substantial changes to the income tax legislation. I use the consumer price index published by Statistics Netherlands to compute real wages (base year is 2005). All observations below the 0.1 th percentile (fl. 1.26) and above the 99.9th percentile (fl. 296.79) are dropped, because wage rates in these areas seem highly unlikely. Figure 2 shows a kernel density estimation of the cleaned variable, which is symmetrically distributed. The average wage rate is 35.36 (2005 real) guilders per hour (s.d. 16.67). Those with a tenure above two years earn more on average (fl. 37.17, s.d. 15.85) than those who are new to their employer (fl. 30.35, s.d. 17.85). As expected, those over 45 earn more on average (fl. 40.55, s.d. 19.13) than their younger counterparts (fl. 33.22, s.d. 15.04).

Figure 3 provides distributional information on the terms of notice in my sample before and after the policy change. Before 1999 the average term of notice was 2.0 months (s.d. 1.5), whereas it was 1.8 months (s.d. 1.1) after 
Figure 3: Histograms of the new and old term of notice $(\mathrm{N}=21,080)$

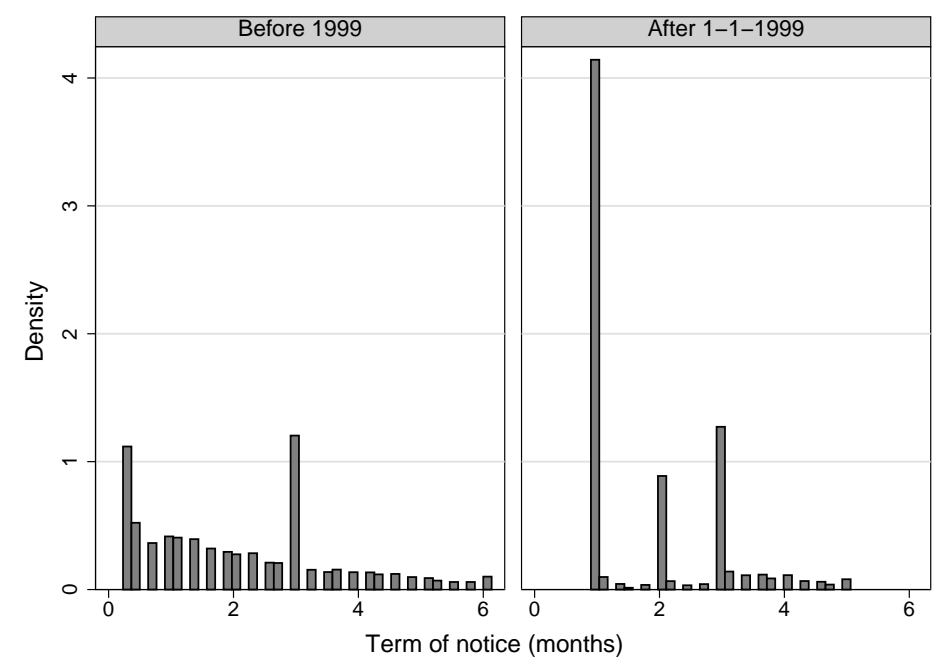

the introduction of the 'Flexwet'. It can be seen in the graph that the new law increased the minimum term and decreased the maximum term. The visible spikes at three months in the first panel and at two months in the second panel result from the 13 weeks maximum term of notice in the old calculation for those under 45 .

Figures A-2 and A-3 in the appendix show histograms of the ages and tenures of the workers in my sample. The average age is 39.5 years (s.d. 9.7) and the average tenure is 9.9 years (s.d. 8.9). The descriptive statistics of these and other independent variables can be found in table A-1 in the appendix.

The regressions presented in the next section include various control variables such as hours worked, dummies for the years 1997 to 2001, a dummy for tenure over two years and a dummy for age over 45 . The lagged wage rate is not included as it doesn't explain a significant proportion of current wages (in my preferred model: coef. .0125, s.e. .0067).

\section{Results}

Table 1 presents the results of the empirical analysis. All three specifications include observations of before and after the 1999 policy change. Hence, multi-collinearity problems can no longer bother the estimates. The first column shows the 'true', unbiased causal effect of the term of notice on wages. The other two columns contain biased coefficients.

My preferred model, in column one, exhibits a highly significant term of notice coefficient of 0.0314 . This means that for each additional month of 
Table 1: Coefficients and standard errors of wage models. Dependent: log of hourly wage rate.

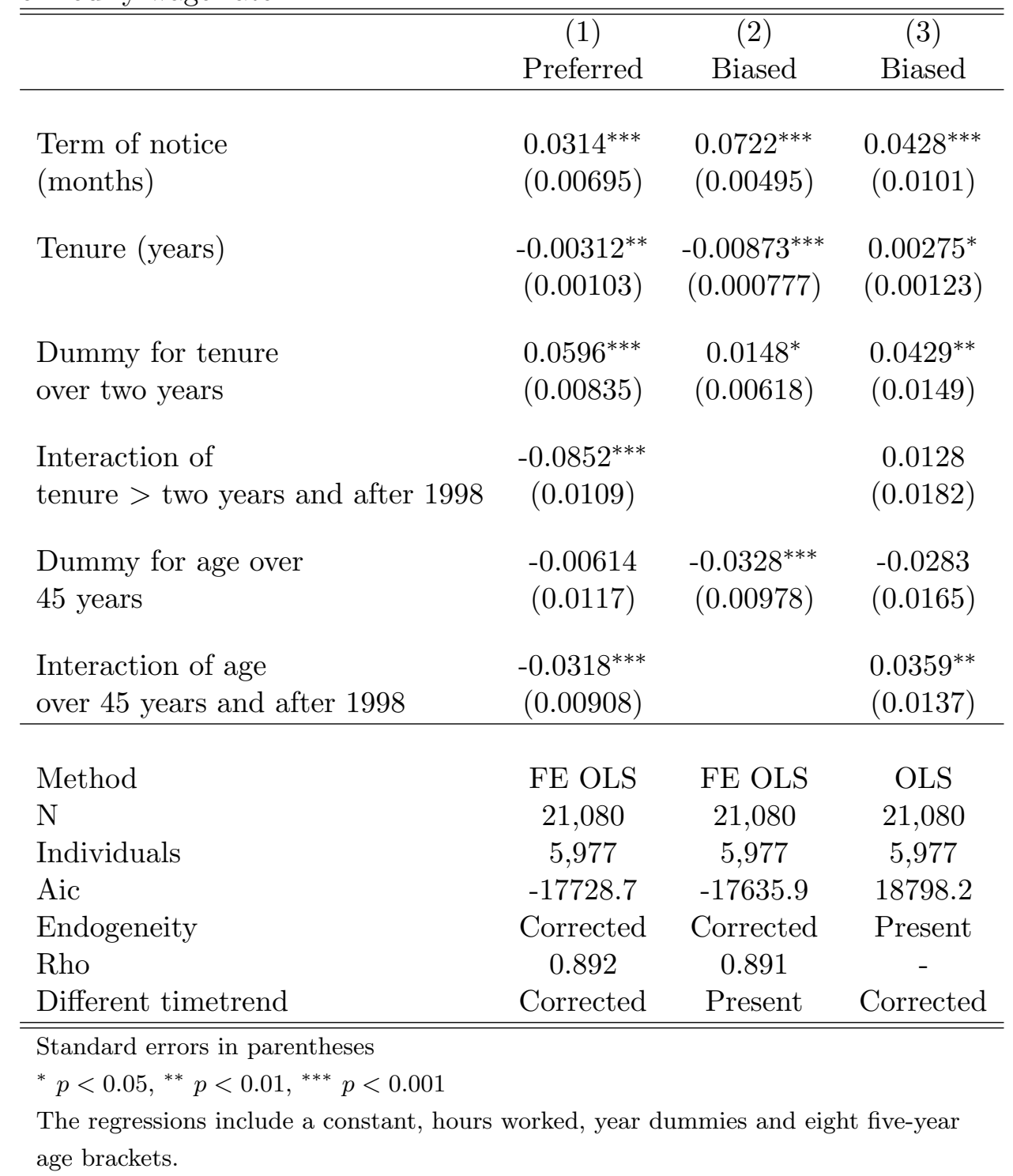


a term of notice the hourly wage rate of a worker goes up by three percent, ceteris paribus. Furthermore I find a negative effect of tenure on wages when I control for all time-invariant individual characteristics. This finding, although contrary to first expectations, replicates those by other authors such as Altonji and Shakotko (1987). In the first column I have also included a dummy for having tenure over two years and a dummy for being older than 45 and the interactions between the policy change period and these dummies. These thresholds were chosen because all workers with a tenure below 3 years experienced a higher term of notice after the policy change and all workers above 45 years with a tenure above two years experienced a lower term of notice.

The estimates show that the wage pay-off for being higher tenured apart from the already described tenure effect changed substantially from the before 1999 to the after 1-1-1999 period. Before 1999, once an individual crossed the two year tenure line his wages went up substantially, i.e. by six percent. However, in the period after the policy change those with a tenure above two years faced 2.5 percent lower wages. A similar structural change affected older workers. Only after 1-1-1999, the fact that a worker was older than 45 had a significant negative impact of three percent on wages, given the other age effects. Apparently, the economic circumstances and other policy changes that coincided with the introduction of the law on flexibility and security were such that these lowered the relative wages of higher tenured and older workers. As the 1999 policy change in the term of notice affected these groups negatively as well, ignoring the differential wage trends overestimates the effect of the term of notice on wages.

In both biased regressions I also find a highly significant positive effect of the term of notice on wages. The estimates in the second column are biased because I ignore the fact that wage trends have been different for low and high tenured and young and older workers over time. The results in column two suggest that an additional legal month of notice increases the wage rate, ceteris paribus, by 7.2 percent, which is a substantial overestimation of the causal impact of the term of notice.

In the third column coefficients and standard errors are presented for a pooled OLS regression ${ }^{9}$ and the regression estimates therefore suffer from an endogeneity problem. The effect of the term of notice on wages is 4.3 percent in this specification and hence larger than in the preferred model. There thus seems to be positive selection into high tenure; i.e. those whose are more inclined to have a high wage and also more inclined to have a high tenure. The time-invariant error term that is correlated with tenure will then drive the term of notice coefficient up. Not controlling for the endogeneity of tenure can hence overestimate the effect of the term of notice on

\footnotetext{
${ }^{9}$ The standard errors in the presented pooled OLS regressions are calculated using a cluster-robust variance matrix.
} 
wages.

Focusing on the unbiased results in the first column of table 1 a clear positive empirical relationship between the term of notice and the wage level is emerging. The marginal effect of an additional month of an employer's notice equals 3.1 percent of the wage rate and is highly significant at the one percent level. For the already described female worker in my sample, aged 50 with 20 years of tenure, who experienced a drop in term of notice from 3.4 months to 2.4 months because of the 1999 policy change, this equals a loss in wage rate of three percent. On a yearly basis this woman, who worked 38 hours a week and earned 38.54 real guilders an hour in 1998, therefore lost 2,285 guilders (i.e. 1,036 euros) because of the change to her employer's term of notice.

Where theory is ambiguous on the sign of the association between the term of notice and wages, my data leaves no doubt. A higher term of notice causally drives wages up, in contrast to the empirical findings of for example Leonardi and Pica (2007). Consequently, a lower term of notice drives wages down.

To check the robustness of these results several additional models were estimated which estimates are displayed in table A-2 in the appendix. All three columns present estimates of models which are similar to the preferred model in table 1. In the model in the first column however, the observations between April 1998 and March 1999 are excluded. This was done to ensure that the causal effect of the term of notice on wages is not the result of wage setting behavior anticipating the January 1999 policy change ${ }^{10}$. As the marginal effect of the term of notice in the first column is even larger than the previously mentioned 3.1 percent, I conclude that this is not the case. In column two and three I separate the sample in male and female workers. Comparing the marginal effects of the term of notice for these two groups, I conclude that the term of notice has an equal size impact on wages of both men and women. Not displayed in table A-2, but still reassuring are the estimates of a model where I exclude the individuals who are only observed at one side of the policy change. The estimated term of notice coefficient namely equals 3.1 as well $(\mathrm{N}=16,683)$.

I thus find evidence that the employer's term of notice has a strong positive causal effect on wages. However, the effect of the term of notice is overestimated when the econometric issues involved are neglected. Nevertheless, a three percent higher wage rate for each additional month of notice is a relevant and substantial side-effect of this type of employment protection.

\footnotetext{
${ }^{10}$ Although I do not find such anticipation, note that such behavior would not contradict but rather emphasize a causal effect of the term of notice.
} 


\section{Conclusion}

This paper establishes the causal effect of the employer's term of notice on the wage level of employees. The legal term of notice is defined as the amount of time a firm is required to notify a worker in advance of her upcoming dismissal. As such, the term of notice is an important component of firing costs and thus of employment protection.

In order to find a causal link, I performed a fixed effects estimation exploiting an exogenous policy change in the term of notice. This procedure corrects for the endogeneity of tenure and for the extreme multi-collinearity between age, tenure and the term of notice. The latter problem arises because age and tenure are the only inputs in the legal formula that calculates the term of notice. The relevant policy change is the 1999 introduction of the law on flexibility and security ('Flexwet') in the Netherlands. This law altered the calculation of the legal term of notice such that the term of notice of low tenured individuals went up and the term of notice of high tenured individuals went down. Six waves of the Dutch Socio-Economic Panel (SEP) were used for the empirical analysis (1996-2001) in which a fixed effects linear regression model is estimated using the logarithm of real gross hourly wages.

The unbiased econometric model in column one of table 1 unveils a very significant, positive causal effect of the 'dormant' term of notice on the wage rate. An increase in the term of notice of one month leads to a three percent higher hourly wage rate. One thing is thus for certain; the arguments presented in Section 2 describing a negative effect of employment protection on wages are incorrect in the analyzed context. This was to be expected for Lazear's (1990) efficiency wage argument as the Dutch labor market institutions do not resemble his competitive model with individual wage-setting. The same could be said for Pissarides' (2001) argument about an endogenous term of notice as the term of notice is decided upon by policy-makers.

The theoretical literature provides two plausible reasons for a positive effect of employment protection on wages. First, insider/ outsider theory suggests that the bargaining position of insiders is enhanced by better protection when unions only represent incumbent workers. In wage negotiations this could then drive wages up. Second, employment protection creates more incentives for firms to invest in workers and for workers to invest in firmspecific human capital. These investments will then lead to higher productivity and higher wages.

More empirical research has to be conducted to decide which of these positive effect theories is best describing reality. In my empirical strategy, I cannot distinguish between the two. To do so, more detailed information on individual employees will be needed. Longitudinal micro-data reflecting individual productivity could address the issue directly. As this data is difficult to obtain, a panel of firm educational investments in their workers could 
be analyzed to indirectly find an answer.

For policy recommendations it is crucial to know what effect on wages is more important: the bargaining or the investment effect. If the wage bargaining argument is stronger, employment protection creates rents for incumbent employees which policy-makers will want to avoid. If however the investment argument holds, employment protection improves the quality of labor which is what policy-makers are seeking. In any case, policy makers should be aware of the positive side-effect of the term of notice on wages. Just thinking about various types of employment protection in terms of employment does not cover their full economic influence.

\section{References}

Altonji, J. and Shakotko, R.: 1987, Do Wages Rise with Job Seniority?, The Review of Economic Studies 54(3), 437-459.

Arulampalam, W., Booth, A. and Bryan, M.: 2004, Training in Europe, Journal of the European Economic Association 2(2-3), 346-360.

Autor, D., Kerr, W. and Kugler, A.: 2007, Do Employment Protections Reduce Productivity? Evidence from U.S. States, IZA Working Paper 2571.

Bentolila, S. and Bertola, G.: 1990, Firing Costs and Labour Demand, Review of Economic Studies 57(3), 381-402.

Bertola, G.: 1990, Job Security, Employment and Wages, European Economic Review 34(4), 851-879.

Bertola, G. and Rogerson, R.: 1997, Institutions and Labor Reallocation, European Economic Review 41(6), 1147-1171.

Blanchflower, D., Oswald, A. and Garrett, M.: 1990, Insider Power in Wage Determination, Economica 57(226), 143-170.

Garibaldi, P. and Violante, G.: 2005, The Employment Effects of Severance Payments with Wage Rigidities, Economic Journal 115(506), 799-832.

Heerma van Voss, G.: 1998, Wet Flexibiliteit en Zekerheid, Actualiteiten Sociaal Recht, 8 edn, Kluwer, Deventer.

Holmlund, B. and Zetterberg, J.: 1991, Insider Effects in Wage Determination: Evidence from Five Countries, European Economic Review 35(5), 1009-1034.

Lazear, E.: 1990, Job Security Provisions and Employment, Quarterly Journal of Economics 105(3), 699-726. 
Leonardi, M. and Pica, G.: 2007, Employment Protection Legislation and Wages, IZA Working Paper 2680.

Lindbeck, A. and Snower, D.: 1986, Wage Setting, Unemployment, and Insider-Outsider Relations, American Economic Review 76(2), 235-39.

Lindbeck, A. and Snower, D.: 2001, Insiders versus Outsiders, Journal of Economic Perspectives 15(1), 165-188.

Nickell, S. and Layard, R.: 1999, Labor Market Institutions and Economic Performance, Vol. 3C of Handbook of Labor Economics, Elsevier, chapter 46, pp. 3029-3084.

Oi, W.: 1962, Labor as a Quasi-fixed Factor, Journal of Political Economy 70(6), 538-555.

Ontslagstatistiek - Jaarrapportage 2002: 2003, Technical report, Ministry of Social Affairs and Employment, The Netherlands.

Pissarides, C.: 2001, Employment Protection, Labour Economics 8(2), 131159.

Smits, W.: 2000, Flexibiliteit en Zekerheid. Verslag van een onderzoek naar de neerslag van de flexwetgeving in CAOs, Technical report, Ministry of Social Affairs and Employment, The Netherlands.

Smits, W. and Samadhan, J.: 2002, Flexibiliteit en Zekerheid. Tweede monitoronderzoek naar de invulling van Flexbepalingen in de CAOs per 1 september 2001, Technical report, Ministry of Social Affairs and Employment, The Netherlands.

Smitskam, C. and Kronenburg-Willems, E.: 2000, Wet Flexibiliteit en Zekerheid, PS Special, 5 edn, Kluwer, Deventer.

Wallerstein, M., Golden, M. and Lange, P.: 1997, Unions, Employers Associations, and Wage-Setting Institutions in North and Central Europe, 1950-1992, Industrial and Labor Relations Review 50(3), 379-401. 
Figure A-1: The ratio of lay-offs through the labor office over the total number of lay-offs (Source: Ministry of Social Affairs and Employment, 2003)

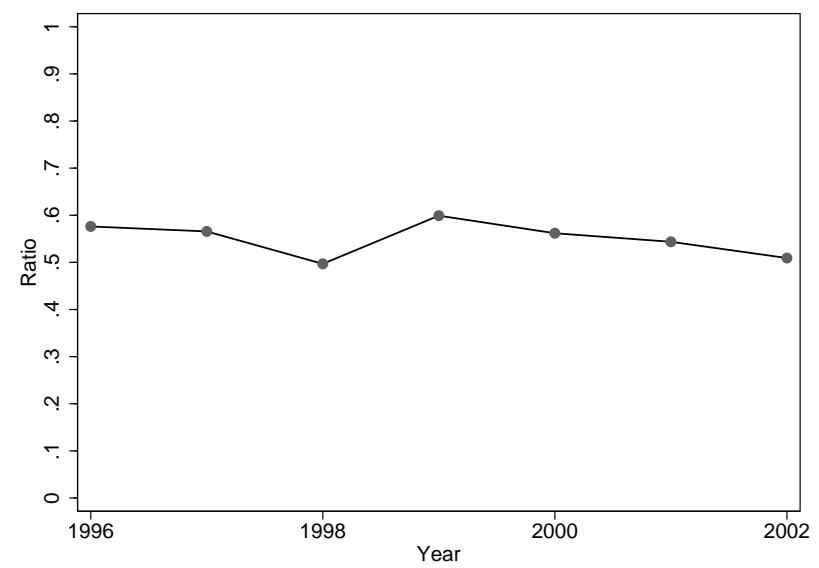

Figure A-2: Histogram of ages $(\mathrm{N}=21,080)$

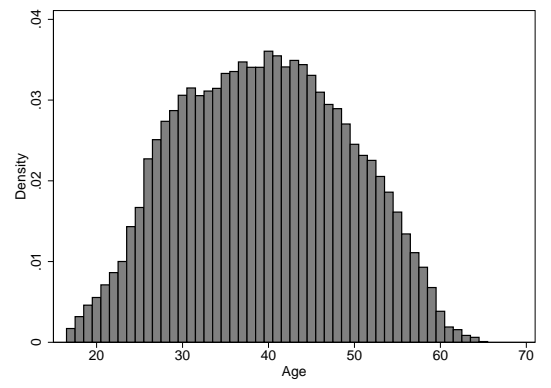

Figure A-3: Histogram of tenure $(\mathrm{N}=21,080)$

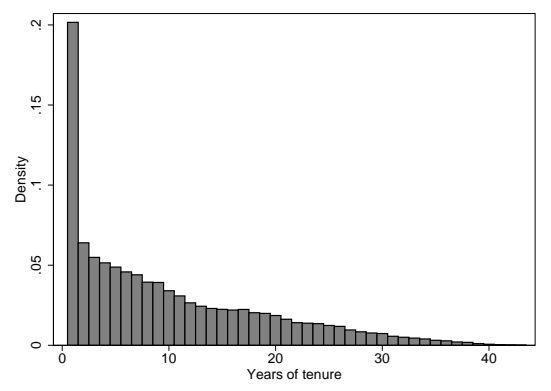


Table A-1: Descriptive statistics of all variables $(\mathrm{N}=21,080)$

\begin{tabular}{|c|c|c|c|c|}
\hline & Mean & S.d. & Min & Max \\
\hline Log gross wage rate (per hour) & 3.473 & 0.434 & 0.237 & 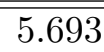 \\
\hline Term of notice (months) & 1.945 & 1.315 & 0.231 & 6.000 \\
\hline Tenure (years) & 9.934 & 8.936 & 1 & 43 \\
\hline Dummy for tenure over two years & 0.734 & 0.442 & 0 & 1 \\
\hline $\begin{array}{l}\text { Interaction of tenure over two years } \\
\text { and introduction new law }\end{array}$ & 0.348 & 0.476 & 0 & 1 \\
\hline Age $16-24$ & \multicolumn{4}{|c|}{ Omitted category } \\
\hline Age $25-29$ & 0.121 & 0.326 & 0 & 1 \\
\hline Age $30-34$ & 0.155 & 0.362 & 0 & 1 \\
\hline Age $35-39$ & 0.170 & 0.375 & 0 & 1 \\
\hline Age $40-44$ & 0.175 & 0.380 & 0 & 1 \\
\hline Age 45-49 & 0.149 & 0.357 & 0 & 1 \\
\hline Age 50-54 & 0.109 & 0.312 & 0 & 1 \\
\hline Age 55-59 & 0.057 & 0.231 & 0 & 1 \\
\hline Age $60-64$ & 0.009 & 0.094 & 0 & 1 \\
\hline Dummy for age over 45 years & 0.291 & 0.454 & 0 & 1 \\
\hline $\begin{array}{l}\text { Interaction of age over } 45 \text { years } \\
\text { and introduction new law }\end{array}$ & 0.156 & 0.363 & 0 & 1 \\
\hline Hours worked (per week) & 36.071 & 10.539 & 1 & 89 \\
\hline Dummy 1995 & \multicolumn{4}{|c|}{ Omitted category } \\
\hline Dummy 1996 & 0.165 & 0.371 & 0 & 1 \\
\hline Dummy 1997 & 0.170 & 0.376 & 0 & 1 \\
\hline Dummy 1998 & 0.165 & 0.371 & 0 & 1 \\
\hline Dummy 1999 & 0.165 & 0.372 & 0 & 1 \\
\hline Dummy 2000 & 0.166 & 0.372 & 0 & 1 \\
\hline Dummy 2001 & 0.168 & 0.374 & 0 & 1 \\
\hline
\end{tabular}


Table A-2: Coefficients and standard errors of wage models - sensitivity analysis. Dependent: $\log$ of hourly wage rate.

\begin{tabular}{|c|c|c|c|}
\hline & $\begin{array}{c}(1) \\
\text { Biased }\end{array}$ & $\begin{array}{c}(2) \\
\text { Biased }\end{array}$ & $\begin{array}{c}(3) \\
\text { Biased }\end{array}$ \\
\hline $\begin{array}{l}\text { Term of notice } \\
\text { (months) }\end{array}$ & $\begin{array}{l}0.0375^{* * *} \\
(0.00809)\end{array}$ & $\begin{array}{l}0.0298^{* * *} \\
(0.00780)\end{array}$ & $\begin{array}{l}0.0311^{*} \\
(0.0130)\end{array}$ \\
\hline Tenure (years) & $\begin{array}{c}-0.00366^{* *} \\
(0.00120)\end{array}$ & $\begin{array}{r}-0.00254^{*} \\
(0.00109)\end{array}$ & $\begin{array}{l}-0.00387 \\
(0.00214)\end{array}$ \\
\hline $\begin{array}{l}\text { Dummy for tenure } \\
\text { over two years }\end{array}$ & $\begin{array}{l}0.0550^{* * *} \\
(0.00914)\end{array}$ & $\begin{array}{l}0.0544^{* * *} \\
(0.00952)\end{array}$ & $\begin{array}{c}0.0688^{* * *} \\
(0.0151)\end{array}$ \\
\hline $\begin{array}{l}\text { Interaction of } \\
\text { tenure }>\text { two years and after } 1998\end{array}$ & $\begin{array}{c}-0.0792^{* * *} \\
(0.0131)\end{array}$ & $\begin{array}{c}-0.0677^{* * *} \\
(0.0122)\end{array}$ & $\begin{array}{r}-0.108^{* * *} \\
(0.0203)\end{array}$ \\
\hline $\begin{array}{l}\text { Dummy for age over } \\
45 \text { years }\end{array}$ & $\begin{array}{r}-0.00975 \\
(0.0133)\end{array}$ & $\begin{array}{r}-0.00586 \\
(0.0127)\end{array}$ & $\begin{array}{r}-0.00782 \\
(0.0227)\end{array}$ \\
\hline $\begin{array}{l}\text { Interaction of age } \\
\text { over } 45 \text { years and after } 1998\end{array}$ & $\begin{array}{c}-0.0355^{* *} \\
(0.0118)\end{array}$ & $\begin{array}{c}-0.0445^{* * *} \\
(0.00994) \\
\end{array}$ & $\begin{array}{l}-0.0116 \\
(0.0176)\end{array}$ \\
\hline $\begin{array}{l}\text { Method } \\
\text { N } \\
\text { Individuals } \\
\text { Aic } \\
\text { Period } \\
\text { Sample } \\
\text { Rho }\end{array}$ & $\begin{array}{c}\text { FE OLS } \\
17,593 \\
5,862 \\
-15638.6 \\
\text { Excl. } 1999 \\
\text { All } \\
0.883\end{array}$ & $\begin{array}{c}\text { FE OLS } \\
12,600 \\
3,387 \\
-13954.1 \\
\text { All } \\
\text { Men } \\
0.903\end{array}$ & $\begin{array}{c}\text { FE OLS } \\
8,480 \\
2,590 \\
-4675.2 \\
\text { All } \\
\text { Women } \\
0.840\end{array}$ \\
\hline $\begin{array}{l}\text { Standard errors in parentheses } \\
{ }^{*} p<0.05,{ }^{* *} p<0.01,{ }^{* * *} p<0.001 \\
\text { The regressions include a constant, hours }\end{array}$ & & & \\
\hline
\end{tabular}

